\title{
Surabaya and Symptom of Sarcasm in Food and Beverage Stalls
}

\author{
Muhammad Fuad Izzatulfikri, Universitas Airlangga \\ Saharani Nurlaila Buamonabot, Universitas Airlangga \\ Khadijah Aufadina, Universitas Airlangga
}

\begin{abstract}
Surabaya as an industrial city presents a wide range of food and beverage industries. The high number of food and beverage store owners has led business owners to present unique and creative names in their line of business. Some sarcastic names are selected and used as store names, such as: Mie Pecun, CakCuk Cafe, Depot Gang Djangkrik, etc. The use of these sarcastic names gradually received a positive response from consumers and successfully influenced the emergence of new stores that use the name sarcasm. This study uses a qualitative method. Data collection techniques were conducted using documentation techniques on 6 food shop logos and 2 beverage logos. Data analysis was done by using descriptive method in the form of reading the data, reducing data, classifying data by type, data interpretation, and drawing conclusion. The theory used in this research is Umberto Eco theory. This theory examines semiotics based on cultural units. The research results obtained from the documentation of the food and beverage logo show that the symptom of sarcasm logo as a cultural unit is inseparable from the identity of the community owned by Surabaya as a coastal and linguistic society namely basa surabayaan. Characteristic forms of sarcasm refer to body shape or physical, typical Surabaya bait, and curse referring to the animals on the logo they display. The sarcasm function in the logo or name used is an expressive form of the creativity of food and beverage owners to show the locality of Surabaya. Symptoms of sarcasm that arise have a strong attachment between the identity of the cultural unit of Surabaya society with the character of modernism development.
\end{abstract}

Keywords: beverage stall; food stall; sarcasm; semiotic Umberto Eco; Surabaya

\section{Introduction}

Surabaya is a major industrial city in East Java. As an industrial city, Surabaya presents a wide range of businesses, such as food industry, beverage industry, textile industry, and so on. According to BPS data of Surabaya (2017: 227), most industries in the Surabaya area are food industries with the total number around 140 industries and the number of workers is around 16,821 .This number is quite high comparing other industries such as the textile industry as many as seventeen industries, the paper industry as much as 36 industries, 55 wood industries, and so forth. The large number of food industries in Surabaya has caused higher competition. This issue causes traders to be more creative by using unique names for their food stalls, taverns, and others. The naming and use of sarcasm names on food and beverage products emerged in the 2000s. Some names of food stalls and taverns in Surabaya such as Mie Pecun (Officially opened on April $2^{\text {nd }}$ 2011), Mie Sexy, CakCuk Cafe, Nasi Goreng Jancuk (Officially opened on April $21^{\text {st }} 2016$ ), PenyetanCok (Officially opened in Jakarta in 2013), Depot Gang Djangkrik, and Jangkrik Caf.

The use of sarcasm language is inseparable from the culture of the people of Surabaya who use the language of pisuhan as a common language and use it in everyday life. In other words, the people of Surabaya enjoy and make that language as one of their styles. Thus, sarcsmis as a way of life and becomes part of their identities. Sarcasm according to Poerwadarminta (in Tarigan, 1990: 92) is a language style that contains mockery or hideous and painful. Then, Keraf (2004: 144) defines sarcasm as a more rough reference of irony and cynicism. Various definitions are rooted in the use of language as a form of interaction and communication.

The naming of food and beverage stalls cannot be separated from the use of language as a form of interaction and communication to consumers. Food and beverage stores that use unique names, attract consumers' interest in visiting the venue. This is in line with Keraf's (2004: 3-4) statement of language function, namely as (1) a tool for expressing self-expression, (2) 
communication tools, (3) tools for social integration and adaptation, (4) social control. The use of language when associated with certain functions and contexts has different meanings. According to Peirce (in Eco,1976) whenever we think, we present to the consciousness of feelings, images, conceptions or other representations, which serve as a sign. In naming food and beverage stores, the sellers use visualization with a logo that refers to a particular sign. The focus of this research is sarcasm names and logos used in food and beverage stores located in Surabaya where the use of sarcasm style tends to be higher compared to other places.

Besides, Surabaya is also a very dynamic place in terms of its culture. Therefore, this study aims to understand further the symptoms of sarcasm that appears in food stalls and beverages. In additions, this study aims to identify and analyze the meanings of sarcasm using Umberto Eco's semiotics theory and reveal the cause of the onset of sarcasm symptoms in food and beverage stalls in Surabaya.

\section{Method of research}

This research uses qualitative approach. The type of research used is descriptive that aims to provide an overview of the facts and reality that are observed appropriately and thoroughly. The data used in this study are divided into two, namely primary data and secondary data. Primary data are obtained from the names of food and beverage stores along with the logos used by the food stalls. Secondary data are in the form of an overview of previous research and literature related to Surabaya, sarcasm, semiotic Umberto Eco, food stores and beverage shops. Data collection techniques were done by documentation techniques at 6 food stalls and 2 taverns. The method used by the researcher to analyze the data is descriptive method in the form of reading the data, reducing data, classifying data by type, data interpretation, and drawing conclusion.

\section{Literature review}

\subsection{Sarcasm}

According to Poerwadarminta (in Tarigan, 1990), sarcasm is a language style that contains mockery or insinuating and painful. Then, Keraf (2004: 144) defines sarcasm as a more rough reference of irony and cynicism. As further clarification stated by Premingear (in Rockwell, 2001), irony is described as something that contradicts the literal meaning of the speaker. In Kamus Besar Bahasa Indonesia, sarcasm is the use of harsh words to hurt the hearts of others; ridicule or ridiculous taunts.

\subsection{Semiotic Umberto Eco}

The basic concept in Umberto Eco semiotics is the sign reading based on cultural units, for example when we read the word $\mathrm{Cak}$ - $\mathrm{Cuk}$, and then the perceptions in our mind will be directly addressed to the people of Arek or the Surabaya community identical with its Jancuk. It proves that the word $\mathrm{Cak}$-Cuk has become a cultural unit that has relationships with other units. In short, through one unit, other units can be aligned or opposed, depending on the existing semantic field. According to Umberto Eco, the semantic field is divided into three parts, namely:

(a) In a culture there may be opposing semantic fields: this peculiar cultural appearance must be considered by semiotics, rather than excluding it; (b)a common cultural unit can be part of a complementary semantic field within a culture; (c) in a culture, a semantic field can be broken into small pieces and rearranged into a new field (Eco, 1976: 80).

In a semantic field, there is a definition that refers to the same semantic network or different and even opposite semantic networks. Interpreting a framework of the theory of code is not simply interpreting it denotatively and connotatively meaning as a solid definition. Understanding a code theory framework is done by formulating the code empirically into the terminology of sign-production theory. Eco formulates the theory of terms sign productions as follows: From the point of sign production theory we can distinguish the denotation from the connotation clearly:

(a)A denotation is a cultural unit or semantic property of a sememe which at the same time is also the property of its culturally recognizable referents; (b) A connotation is a cultural 
unit or semantic property of a sememe delivered by its denotation and may not necessarily correspond to its culturally recognizable reference property.

\section{Discussion}

Sarcasm food and beverage store spread all over Surabaya area, especially in Mall area, Hotel, University, and others. Some names that use sarcasm are Mie Pecun, Mie Sexy, CakCuk Cafe, Nasi Goreng Jancuk, Penyetan Cok, Depot Gang Djangkrik, and Jangkrik Cafe. Here is the name of the food and beverage stores and the addresses:

Table 1: Sarcasm in Food Stalls

\begin{tabular}{|l|l|}
\hline \multicolumn{1}{|c|}{ Name } & \multicolumn{1}{|c|}{ Address } \\
\hline Mie Pecun & $\begin{array}{l}\text { Jl. Kedungsari No.135A, Wonorejo, Tegalsari, Kota Surabaya } \\
\text { Surabaya, Jawa Timur 60263 }\end{array}$ \\
\hline Mie Sexy & $\begin{array}{l}\text { Jl. Pulo Wonokromo No. 285-A, Wonokromo, Kota Surabaya, Jawa } \\
\text { Timur 60243 }\end{array}$ \\
\hline Mie CakCuk & Jl. Ketintang No. 133A, Surabaya \\
\hline Cafe CakCuk & $\begin{array}{l}\text { Jl. Frontage Ahmad Yani Siwalankerto No.263, Siwalankerto, } \\
\text { Wonocolo, Kota Surabaya, Jawa Timur 60234 }\end{array}$ \\
\hline Nasi Goreng Jancuk & $\begin{array}{l}\text { Foodcourt TP 1 Lt.5, Foodcourt Royal Plaza Lt. 3, Foodcourt } \\
\text { Surabaya Plaza Lt. 4 }\end{array}$ \\
\hline PenyetanCok & $\begin{array}{l}\text { Foodcourt Cito (City of Tomorrrow), Foodcourt Transmart Carrefour } \\
\text { Rungkut Lt. Ground, Foodcourt Royal Plaza Lt. 3, Foodcourt Delta } \\
\text { Plaza Surabaya Lt. 4, Foodcourt Kaza City Lt. Ground, Jl. Kranggan } \\
\text { Gg. V No. 28 Bubutan. }\end{array}$ \\
\hline Depot Gang Djangkrik & $\begin{array}{l}\text { Ruko Grand Sungkono, Jl. Mayjen Sungkono No. 176-178, Dukuh } \\
\text { Pakis, Surabaya, Jawa Timur, 60225 }\end{array}$ \\
\hline Jangkrik Café & $\begin{array}{l}\text { Jalan Raya Jemur Sari No.107, Jemur Wonosari, Wonocolo, Jemur } \\
\text { Wonosari, Wonocolo, Kota Surabaya, Jawa Timur 60237 }\end{array}$ \\
\hline
\end{tabular}

\subsection{Mie pecun and miee sexy}

Mie Pecun (pecun noodles) is a food stall that sells various types of noodle. When viewed its denotation, Pecun is an acronym used in the world of sex, namely Free Women. This term originally came from Jakarta which then spread to various cities, including Surabaya. Pecun is a name that tends to be sarcastic, because it deals with the body, the night world and sex. On the Pecun Mie logo there is a red chili picture and a female picture (replacing the letter $\boldsymbol{i}$ on the word mie in Figure 1). The term Pecun in Mie Pecun is not in the context of the true meaning of Pecun. However, Pecun here has a different meaning from the general one. The meaning of Pecun has connotation as an acronym of toxic-free noodle, which means that this food stall sells various types of noodles that have a spicy and poison-free taste. Poison-free here means a spicy sensation that comes from noodles derived from natural peppers without chemicals.

Figure 1. The Logo of Mie Pecun

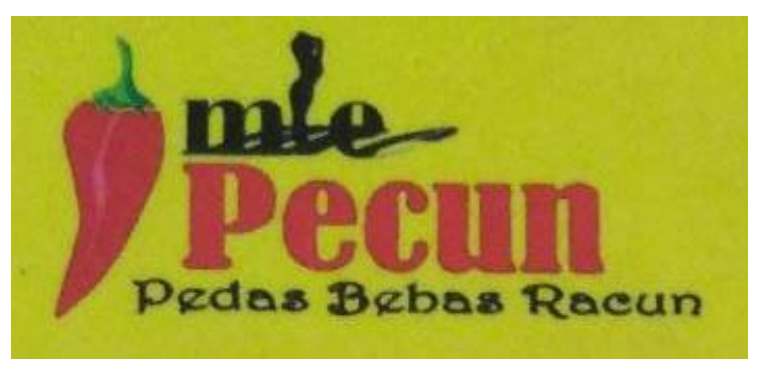

Figure2. The logo of Mie Sexy

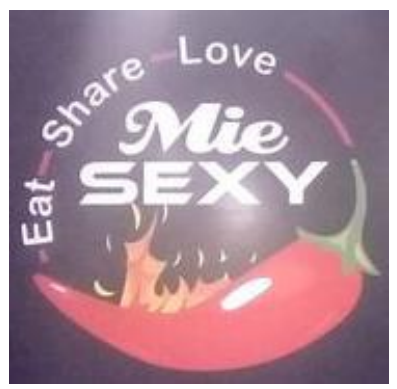


Mie Sexy (sexy noodles) is a food stall that also sells various types of noodles. Figure 2 above is a logo of Sexy Mie. On the logo there is a burning chili picture, the name of the food stall (Mie Sexy) and tagline (Eat, Share, Love). The use of the logo name is a combination of two languages, Indonesian (Mie) and English (Sexy). According to the KBBI dictionary, sexy means something that stimulates lust (body shape, clothing, etc.). It connotatively means a kind of noodle that has a spicy flavor that stimulates the tongue.

\subsection{Mie cak-cuk, Cafe cakcuk, nasi goreng jancuk, and penyetan cok}

Mie Cak-Cuk, Cuk Cafe, Jancuk fried rice and Penyetan Cok uses the term sarcasm which is a typical of Surabaya. It is in the form of expletives and sarcasm. Swear words are words that are likely to be shunned by the community because of the record consider the words felt disrespectful when is pronounced (Crystal, 1995). However, for the people of Surabaya, swear words in certain contexts is a form of proximity of someone's close relationship when interacting. Some swear and bad word term that is used in the name of food and drink stalls are Jancuk, Cak and $\mathrm{Cuk}$, Cok. Note the figure below:

Figure 3. The logo of CafeCakCuk

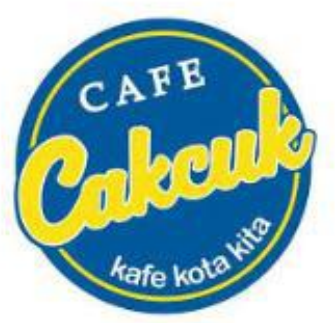

Cafe CakCuk is one of arek Suroboyo community hangout place. It provides a variety of menu specialties, like Rujak Cingur, Lontong Kupang, and so on. The cafe uses diction CakCuk. This term is often used by community arek (society of Surabaya) in daily life. Duke's (2014:31) explained that the $C a k$ is a reference to older people in Indonesia, while the $C u k$ is a term used by people in East Java to indicate the closeness of the relationship, especially on the daily conversation in the Surabayaan dialect. With the tagline Our Town Cafe show that Cafe CakCuk is a typical cafe in Surabaya.

Figure 4. The logo of Mie Cak-Cuk

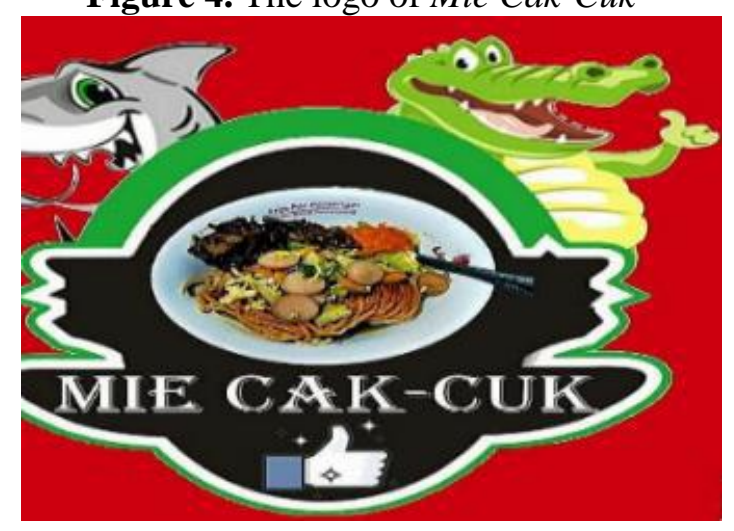

Mie Cak-Cuk is a food stalls selling noodles, too. Logo of Mie Cak-Cuk uses the symbol of Surabaya; that is the image of Sura (Whales) and Baya (Crocodile). Generally in denotative meaning, this logo indicates that Mie Cak-Cuk is a kind of food that is derived from Surabaya. In connotative meaning, it is a symbol of Surabaya which shows that such food is originated from Surabaya. 
Figure 5. The logo Nasi Goreng Jancuk

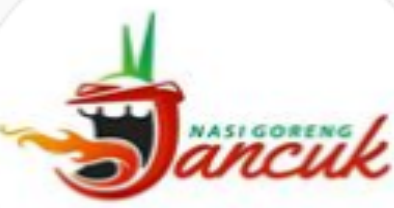

Figure 6. Penyetan Cok

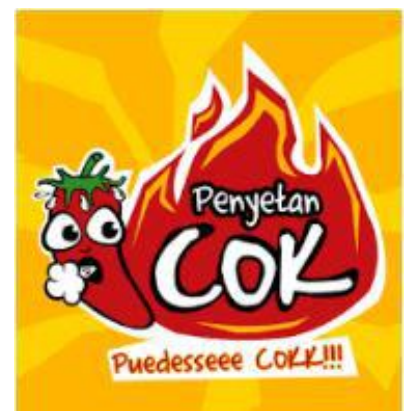

Two logos above have similarities in using use of the image of burning chillies. Figure 5 shows that his tongue is being burned and Figure 6 shows smoke coming out from the mouth of the chili and there is fire behind it. But both of these food stalls differ in terms of the food sold. Jancuk special fried rice provides a menu of fried rice whereas Penyetan Cok provides any kinds of penyetan like tovu, fish and others. Jancuk fried rice uses diction Jancuk, while Penyetan Cok uses diction Cok and the tagline Puedesseee Cokk!!! in its logo. Jancuk and Cok is the typical pisuhan and swear in Surabaya. In terms of meaning, Jancuk and Cok have the same meaning. Jancuk and Cok refer to sexual activities which are generally carried out by husband and wife.It is taboo to pronounce. It connotatively means the consumers might feel spicy as if his tongue is burning, so that they use these pisuhan (Jancuk, Puedesseee Cok) to express their feeling.

\subsection{Depot gang djangkrik and kafe jangkrik}

Depot Gang Djangkrik and Kafe Jangkrik using the term sarcasm that is a curse referring to an animal, which is crickets. In denotative meaning, crickets are a type of insect that usually lives in the soil (rice field), brown or black, double winged, chirping a krik, krik sound.

Depot Gang Djangkrik is a place selling Chinese food such as noodles and pork. The naming of the Depot Gang Djangkrik uses old spelling (Djangkrik).In the logo is the image of cricket. While in connotation meaning, this food stall does not sell cricket menu, but it is a term of pisuhan used to create a unique sense on the name of the food store.

Figure 7. Depot Gang Djangkrik

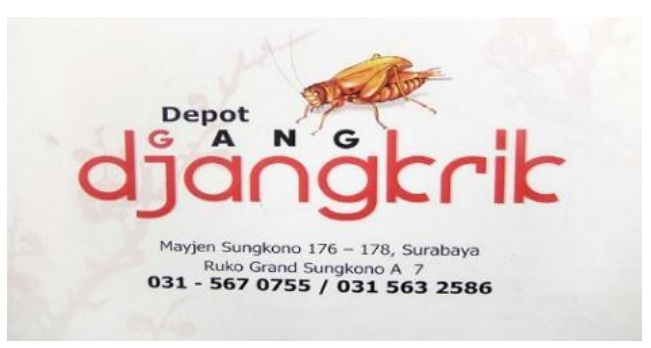

Figure 8. Kafe Jangkrik

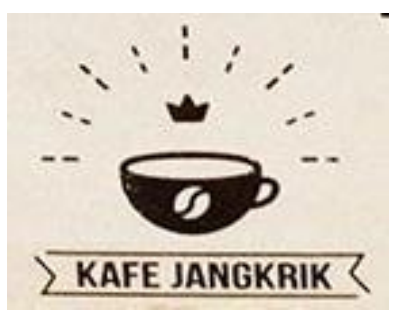

Kafé Jangkrik is a tavern that sells various types of beverages such as coffee, tea, and so forth. From the logo in Figure 8 we can see that there is no image of jangrik, but there is a picture of coffee cup. Based on the denotative and connotative meaning in the logo of food stalls and taverns above, there is a sarcastic meaning aligned with the context of the language of Surabaya society which tends to be rough and egalitarian. Characteristics of sarcasm form in the food and beverage shop in Surabaya refers to the physical or body shape (two logos), four logos of typical Surabaya curse, and a curse that refers to the animal as much as two logos. In analyzing the sarcasm language style it is not enough to understand the meaning only, but it must be interpreted extensively (Camp, 2012). The use of sarcasm in the food and beverage stall is not a true form of pisuhan and curse. In fact, the function of the sarcasm is a form of creativity of food and beverage 
owners to attract consumers. Negative connotation words are used as a form of promotion to the consumers. In general, the people of Surabaya like spicy food, so it is represented by the burning of chili peppers and unique and creative names.

\section{Conclusion}

Some names of food and beverage shops are identified through the logo as an odd semantic cultural unit, because the language of sarcasm in the name of the store is not a common thing. This indicates the existence of semantically sarcastic signs symptom that occur in the culture of Surabaya and the in basa surabayaan they use. The characteristic of sarcasm forms not only in connotative and denotative terms, but rather as a code framework on body or physical form, typical Surabaya swearing, and curses referring to animals arising in cultural units. The sarcasm function in the logo or name they use is an expressive form of the creativity of the owner of the food and beverage shop to show their identity as Surabaya citizens. Symptoms of sarcasm that arise have a strong attachment between the identities of the cultural unit of Surabaya society with the character of modernism development.

\section{References}

Bangsawan, A. 2014. Lokalitas konten dalam visual kaos Cak-Cuk Surabaya. Jurnal Artika, $1(1), 29-37$.

Camp, E. 2012. Sarcasm, pretense, and the semantics/pragmatics distinction. Nô̂s, 46(4), 587634.

Crystal, D. 1995. The Cambridge Encyclopedia of the English language. Cambridge: Cambridge University Press.

Eco, U. 1976. A theory of semiotics. London: Indiana University Press.

Kamus Besar Bahasa Indonesia. Available at https://kbbi.kemdikbud.go.id/entri/jangkrik. (Accessed June 2, 2018).

Kamus Besar Bahasa Indonesia. Available at https://kbbi.kemdikbud.go.id/entri/sarkasme. (Accessed 2 June 2018).

Keraf, G. 2004. Diksi dan gaya bahasa. Jakarta: Gramedia.

Keraf, G. 2004. Komposisi. Semarang: Bina Putera.

Rockwell, P. 2001. Facial expression and sarcasm. Perceptual and Motor Skills, 93, 47-50.

Tarigan, H. G. 1990. Pengajaran gaya bahasa. Bandung: Angkasa. 